\title{
Pengaruh Celup Puting Menggunakan Ekstrak Buah Mengkudu Matang terhadap Jumlah Sel Somatik Sapi Perah Mastitis Subklinis
}

Theresia Ika Purwantiningsih

Fakultas Pertanian, Universitas Timor, Kefamenanu, TTU - NTT, 85613, Indonesia.

\section{Article Info}

\section{Article history:}

Received 10 April 2016

Received in revised form 25 Mei 2016 Accepted 17 Juni 2016

Keywords:

Celup puting, mastitis, mengkudu,

sel somatik

\section{Abstrak}

Mastitis menjadi masalah utama dalam tata laksana usaha peternakan sapi perah karena dapat menurunkan produksi susu dalam jumlah besar. Celup puting adalah salah satu cara untuk meminimalisir penyebaran bakteri penyebab mastitis. Tujuan penelitian ini adalah untuk mengetahui pengaruh celup puting menggunakan ekstrak buah mengkudu (Morinda citrifolia) matang terhadap jumlah sel somatik sapi perah yang menderita mastitis subklinis. Penelitian ini menggunakan empat ekor sapi Friesian Holstein (FH) yang diketahui menderita mastitis sub klinis. Puting sapi FH dicelup menggunakan ekstrak buah mengkudu matang konsentrasi $30 \%$ dan $40 \%$ dalam kurun waktu satu bulan. Perhitungan jumlah sel somatik dihitung setelah celup puting dilakukan. Celup puting secara signifikan $(\mathrm{P}<0,05)$ dapat mengurangi jumlah sel somatik pada sapi perah yang menderita mastitis sub klinis. Larutan ekstrak buah mengkudu matang konsentras $40 \%$ lebih baik dalam mengurangi jumlah sel somatik. (2016 dipublikasikan oleh JAS.

\section{Pendahuluan}

Sanitasi pemerahan merupakan salah satu hal penting dalam tata laksana pemeliharaan sapi perah. sebagian besar peternak sapi perah di Indonesia kurang peduli dengan sanitasi setelah pemerahan. Hal ini memicu timbulnya penyakit mastitis. Mastitis secara umum didefinisikan sebagai peradangan jaringan internal ambing. Peradangan pada ambing ini disertai dengan perubahan fisik, kimia, mikrobiologi dan adanya kenaikan jumlah sel radang (jumlah sel somatik/Somatic Cell Count), terutama leukosit dalam susu dan dapat disertai dengan perubahan patologi pada jaringan ambing, yang disebabkan oleh infeksi dua golongan bakteri yaitu bakteri Gram positif dan Gram negatif (Sufiriyanto and Indraji, 2005). Penyakit ini sangat merugikan peternak karena menyebabkan produksi susu menurun (Sudarwanto and Sudarnika, 2008)

Salah satu cara yang digunakan peternak untuk meminimalisir terjadinya mastitis adalah dengan pencelupan puting (teat dipping). Menurut Schmidt $e$ al. (1984), celup puting selama masa laktasi dapat mengurangi infeksi intramammary sebesar 50\%. Celup puting efektif dalam mengurangi infeksi yang disebabkan oleh bakteri. Di banyak kawanan ternak, infeksi berkurang ketika celup puting dilakukan. Larutan yang biasa digunakan untuk celup puting adalah iodine. Telah ditemukan peningkatan residu iodine yang signifikan di dalam susu jika menggunakan $1 \%$ iodine untuk celup puting. Residu iodine di dalam susu meningkat dari $80 \mathrm{ke} 100 \mu \mathrm{g} / \mathrm{L}$ ketika $1 \%$ iodine digunakan untuk celup puting. Kandungan iodine di dalam susu tidak terlalu berpengaruh terhadap kesehatan manusia, tetapi peningkatan pemakaian dari pakan yang mengandung iodine dan cairan pembersih ambing yang menggunakan iodine menyebabkan meningkatnya konsumsi manusia akan iodine (Boodie and Nickerson, 1989)

Mengingat residu iodine yang terdapat di dalam susu dapat meningkatkan konsumsi iodine pada manusia, maka salah satu alternatif adalah menggunakan bahan alam untuk campuran celup puting. Mengkudu (Morinda citrifolia) adalah salah satu pilihannya. Buah mengkudu memiliki aktivitas antibakteri, antiviral, antifungi, antitumor, antihelmik, analgesik, hipotensif, antiinflamas dan efek peningkatan imun (Usha et al., 2010). Kandungan fenol sebagai zat antibakteri dalam buah mengkudu dapat menghambat bakteri Gram Positif. Di mana sebagian besar kasus mastitis disebabkan oleh Staphylococcus aureus dan Streptococcus agalactie yang merupakan bakteri Gram positif (Irianto, 2006) Diharapkan dengan melakukan celup puting menggunakan mengkudu, jumlah sel somatik yang terdapat pada sapi perah yang menderita mastitis sub klinis dapat berkurang sehingga mengurangi kasus mastitis di Indonesia.

\section{Metode}

Penelitian ini menggunakan enam ekor sapi Peranakan Friesien Holstein (PFH) yang terkena mastitis subklinis. Diagnosa mastitis subklinis menggunakan uji California Mastitis Test (CMT). Penelitian dilakukan di UPT. Ternak Perah Fakultas Peternakan Universitas Gadjah Mada.

Materi untuk diagnosa mastitis adalah larutan CMT dan paddle. Materi untuk celup puting adalah larutan ekstrak mengkudu matang konsentrasi $30 \%$ dan $40 \%$ dan dipper. Materi untuk penghitungan jumlah sel somatik adalah aquades, alkohol eter, alkohol 96\%, larutan methylene blue, gelas objek yang bebas dari lemak, pipet Breed steril, lampu bunsen, mikroskop dan ose siku.

Diagnosa mastitis dilakukan dengan mengambil $2 \mathrm{ml}$ susu segar dari setiap puting sapi sampel. Susu tersebut diletakkan di paddle CMT dengan posis vertikal. Larutan CMT ditambahkan ke masing-masing bagian paddle kemudian paddle CMT diputar, sehingga susu dan larutan CMT tercampur. Proses pencampuran tidak lebih dari 10 detik. Hasil yang terlihat dalam paddle CMT dibaca dengan cepat karena reaksi yang terlihat akan rusak dalam 20 detik. Penilaian reaksi ini secara visual. Lebih banyak gel yang dibentuk, semakin besar nilainya. Hasil pengujian CMT menurut (Mellenberger and Roth, 2000) ditentukan sebagai berikut negatif (tidak terinfeksi) ditanda dengan tidak terdapat gumpalan dan sangat encer, trance (sangat ringan dan kemungkinan terjadi infeksi) ditandai dengan adanya gumpalan dan reaksi in akan menghilang jika paddle diputar lagi, positif 1 (infeksi ringan) ditanda dengan larutan yang mengental akan tetapi tidak condong menjadi gel, jika paddle diputar lebih dari 20 detik kekentalan menghilang, positif 2 (terinfeksi) ditandai dengan terjadi gumpalan dan membentuk gel yang ringan, campuran akan menggumpal di tengah paddle dan akan melapisi bagian bawah apabila dibuang dan positif 3 (terinfeksi kuat) ditandai dengan terbentuknya gel yang sangat kental dan sulit untuk digerakkan.

Celup puting menggunakan ekstrak buah mengkudu dilakukan selama sebulan. Keempat puting sapi perah mastitis subklinis dicelup selama 5 sampa 10 detik. Setelah celup puting selesai, penghitungan jumlah sel somatik dilakukan.

Penghitung jumlah sel somatik dilakukan dengan menyebarkan $0,01 \mathrm{ml}$ susu di atas gelas objek hingga mencapai luas $1 \mathrm{~cm}^{2}$ dan kemudian diwarnai dengan methylene blue. Gelas objek bebas lemak disiapkan kemudian diberi tanda yang menunjukkan asal contoh susu. Gelas objek diletakkan di atas kertas yang sudah berisi gambar kotak seluas $1 \mathrm{~cm}^{2}$. Contoh susu diambil menggunakan pipet Breed sebanyak 0,01 ml ke daerah yang dibatasi kotak, contoh susu disebarkan sehingga menutupi seluruh siku kotak (seluas $1 \mathrm{~cm}^{2}$ ) Preparat dikeringkan di udara sampai kering (5 sampai 10 menit), kemudian difiksasi di atas nyala api. Pewarnaan dilakukan dengan cara mencelupkan preparat ke dalam alkohol-eter selama 2 menit, kemudian preparat dimasukkan ke dalam methylene blue selama 1 menit, setelah itu dibilas secara hati-hati dengan aquades. Preparat lalu dicelupkan ke dalam alkohol 96\% (untuk membersihkan bahan pulasan yang tidak terikat). Preparat dikeringkan di udara atau dengan kertas pengisap. Penetapan jumlah sel somatik dilakukan dengan melihat banyaknya jumlah sel somatik di lima lapang pandang melalui bantuan mikroskop dengan perbesaran kuat.

Menurut (Handayani and Purwanti, 2010), jumlah sel somatik dihitung menggunakan rumus:

$$
\begin{array}{lll}
\mathbf{N}=\text { FM } \mathbf{n} \times 100 & \\
\text { Keterangan : } & \mathrm{N} & =\text { jumlah sel somatik } \\
& \mathrm{FM} & =\text { faktor mikroskop (100) } \\
\mathrm{n} & =\text { rata-rata jumlah pada } 5 \text { lapang pandang }
\end{array}
$$

\section{Hasil dan Pembahasan}

Celup puting menggunakan ekstrak buah mengkudu diharapkan mampu mengurangi jumlah SCC di dalam susu sapi yang diduga terkena mastitis. Hasi rataan perhitungan SCC yang diperoleh sebelum dan sesudah pencelupan dengan ekstrak buah mengkudu dapat dilihat pada Tabel 1.

Tabel 1. Rata-rata hasil penghitungan SCC sebelum dan sesudah perlakuan Rata-rata jumlah SCC dalam sampel susu $\left(\times 10^{4} \mathrm{sel} / \mathrm{ml}\right)$

\begin{tabular}{cccccccc}
\hline & \multicolumn{3}{c}{ Kata-rata jumlah SCC dalam sampel susu (x10 sel/ml) } \\
\hline \multirow{2}{*}{ No. Sapi } & \multicolumn{3}{c}{ Konsentrasi 30\% } & $\begin{array}{c}\text { No. } \\
\text { Sapi }\end{array}$ & \multicolumn{3}{c}{ Konsentrasi 40\% } \\
\hline & Sebelum & Setelah & $\begin{array}{c}\text { Level } \\
\text { penurunan }\end{array}$ & & Sebelum & Setelah & $\begin{array}{c}\text { Level } \\
\text { penurunan }\end{array}$ \\
\hline E51 & 17,53 & 6,35 & 11,18 & D03 & 8,30 & 7,45 & 0,85 \\
F05 & 10,98 & 5,50 & 5,48 & F01 & 14,48 & 7,78 & 6,70 \\
G01 & 12,98 & 7,58 & 5,40 & F03 & 12,53 & 9,20 & 3,33 \\
Jumlah & 41,49 & 19,43 & 22,06 & & 35,31 & 24,43 & 10,88 \\
\hline
\end{tabular}

Level penurunan jumlah SCC untuk konsentrasi $30 \%$ adalah $66,97 \%$ dan level penurunan jumlah SCC untuk konsentrasi $40 \%$ adalah $33,03 \%$. Konsentrasi ekstrak buah mengkudu yang lebih efektif untuk celup puting adalah $30 \%$ karena setelah pencelupan level penurunannya lebih besar daripada konsentrasi $40 \%$.

Menurut (Subronto, 2003), jumlah sel mencerminkan beratnya proses radang kelenjar susu. Sel-sel di dalam susu terdiri dari sel monokuler besar (65 sampai 70\%), netrofil (0 sampai 8\%), limfosit (kurang lebih 5\%) dan kadangkadang juga monosit. Sel-sel yang mengalami degenerasi sebanyak 18 sampai $25 \%$. Dalam keadaan infeksi berat, hingga menyebabkan radang hebat, jumlah netrofil melonjak dengan drastis dari 90 sampai $95 \%$. 
Perangkat pertahanan mekanis yang sangat penting terdapat dalam saluran ujung puting susu yang dikenal sebagai ductus papilaris (streak canal). Permukaan saluran terdiri atas epitel pipih berlapis (stratified squamose epithelium) yang selalu mengalami keratinisasi, dengan sebum atau keratin yang mengandung lipid dan protein yang bersifat bakterisidal maupun bakteriostatik pada permukaan epitelnya. Apabila keratin dihilangkan dengan jalan dikerok, kemampuan bertahan kelenjar terhadap infeksi kuman menjadi sangat menurun (Subronto, 2003).

Perangkat pertahanan seluler berupa sel darah putih yang mampu melakukan fagositosis. Susu curahan pertama (foremilk) mengandung 250 sampai 500.000 sel darah putih dan susu biasa mengandung 0 sampai 200.000 sel tiap milimeternya. Apabila fagositosis tidak berhasil menghentikan infeksi kuman maka akan terjadi proses radang, yang segera akan diikuti dengan mobilisasi sel darah putih. Di dalam susu juga terdapat opsonin yang memudahkan proses fagositosis. Meskipun proses fagositosis terhadap kuman di dalam susu tidak seefisien seperti halnya jaringan atau pembuluh darah, proses fagositosis tetap merupakan alat pertahanan yang sangat penting dalam menanggulangi pembentukan koloni kuman yang berhasil masuk ke dalam sisterna. Efektivitas fagositosis yang tidak begitu tinggi disebabkan karena kurangnya glikogen serta terlalu banyak lemak dan kasein (Subronto, 2003).

Menurut (Dohoo and Meek, 1982), ada beberapa faktor yang mempengaruhi jumlah SCC yang pertama adalah status infeksi, faktor terpenting dari jumlah SCC di dalam susu adalah jumlah kuartir yang terinfeksi dalam individu sapi. Rata-rata jumlah SCC dalam kuartir yang tidak terinfeksi adalah $260.000 \mathrm{sel} / \mathrm{ml}$ dan jumlah SCC dari sapi yang mempunyai sejarah terinfeksi adalah $314.000 \mathrm{sel} / \mathrm{ml}$. Faktor yang kedua yaitu jumlah kuartir yang terinfeksi, semakin banyak kuartir yang terinfeksi maka jumlah SCC dalam susu individu sapi semakin banyak karena konsentrasi sel somatik dalam susu sapi dihitung berdasarkan jumlah sel somatik dalam empat kuartir.

Dohoo dan Meek (1982) menambahkan faktor yang ketiga adalah umur sapi, beberapa penelitian menunjukkan bahwa peningkatan SCC berbanding lurus dengan meningkatnya umur sapi. Peningkatan ini terjadi karena lebih banyak kuartir yang terinfeksi, kerusakan jaringan karena infeksi yang lama dan respon yang lebih besar di kuartir yang sebelumnya telah terinfeksi. Faktor berikutnya adalah umur laktasi, sel somatik ditemukan akan meningkat dengan segera setelah sapi partus meskipun sapi tersebut tidak terinfeksi. SCC meningkat seiring dengan peningkatan laktasi. Dan faktor terakhir adalah manajemen pemeliharaan, teratur melakukan celup puting setelah pemerahan dapat mengurangi jumlah SCC.

Menurut (Subronto, 2003), peranan pemerah dan peralatan pemerahan juga menentukan terjadinya mastitis di suatu kandang. Apabila pemerahan dilakukan menggunakan mesin, kejadian mastitis lebih tinggi dibandingkan dengan pemerahan secara manual. Frekuensi pemerahan juga berpengaruh terhadap kejadian mastitis. Di Israel telah dibuktikan bahwa sapi-sapi yang diperah tiga kali sehari menunjukkan angka mastitis yang lebih rendah daripada sapi-sapi yang diperah dua kali atau sekali sehari. Kebiasaan membiarkan pedet menyusu induk sampai pedet tersebut berumur beberapa bulan juga menjadi penyebab terjadinya mastitis. Mulut pedet merupakan alat yang efektif dalam penyebaran kuman dari ambing yang terinfeksi ke ambing lain yang sehat. Kadang-kadang ditemukan bahwa seekor pedet menyusu pada lebih dari satu induk, hingga pedet tersebut dapat menularkan mastitis dari sapi yang satu ke sapi yang lain.

Lee (2012), menambahkan, faktor lain yang menyebabkan perbedaan jumlah SCC adalah nutrien, nutrien sangat penting dalam menjaga kekebalan tubuh. Kekurangan nutrien atau kekurangan energi dapat menyebabkan sapi kekurangan kemampuan untuk menahan infeksi. Keseimbangan nutrien dapat meningkatkan sistem kekebalan untuk menyerang bakteri patogen.

\section{Simpulan}

Penambahan ekstrak buah mengkudu sebagai bahan untuk celup puting mampu mengurangi jumlah sel somatik di dalam susu dari ambing yang terinfeksi. Semakin sedikit jumlah sel somatik yang ada di dalam susu mengindikasikan bahwa infeksi yang terjadi semakin minim. Konsentrasi ekstrak buah mengkudu $30 \%$ sudah dapat menghambat bakteri penyebab mastitis.

\section{Pustaka}

Boodie, R.L., Nickerson, S.C., 1989. Efficacy of .18\% Iodine Teat Dip Against Staphylococcus aureus and Staphylococcus Agalactiae. J Dairy Sci 72, 1063-1066.

Handayani, K. S, M. Purwanti, 2010. Kesehatan Ambing dan Higiene Pemerahan di Peternakan Sapi Perah Desa Pasir Buncir Kecamatan Caringin. J. Penyul. Pertan. 5:47-54.

Irianto, K., 2006. Mikrobiologi, I. ed. Yrama Widya, Bandung.

Lee, D. L, 2012. Factors Influencing Somatic Cell Count Variation in Cow Milk Samples. SCC Var. Artic. State Univ. NJ.

Mellenberger, R., Roth, C.J., 2000. California Mastitis Test (CMT). Fact Sheet.

Dohoo, R., I., A. H Meek, 1982. Somatic Cell Count in Bovine Milk. Dep. Vet. Microbiol. Immunol. Can Vet J. 23:119-125.

Subronto, 2003. Ilmu Penyakit Ternak. Gadjah Mada University Press, Yogyakarta.
Sudarwanto, M., Sudarnika, E., 2008. Hubungan antara pH Susu dengan Jumlah Sel Somatik Sebagai Parameter Mastitis Subklinik. Media Peternak. 31, 107-113.

Sufiriyanto, Indraji, M., 2005. Uji In Vitro dan In Vivo Ekstrak Campuran Mengkudu (Morinda citrifolia) dan Bawang Putih (Allium sativum) pada Sapi Perah Penderita Mastitis Sub Klinis. J Anim. Prod. 7, 101-105.

Usha, R., Sangeetha, S., Palaniswamy, P., 2010. Antimicrobial Activity of Rarely Known Species, Morinda citrifolia. LEthnobotanical Leafl. 14:30611. 